\title{
Puccinia coronata f.sp. avenae VIRULENCE IN CENTRAL AND SOUTH-EASTERN POLAND IN 2014
}

\section{WIRULENCJA Puccinia coronata f.sp. avenae W CENTRALNEJ I POŁUDNIOWO-WSCHODNIEJ POLSCE W 2014 ROKU}

Institute of Plant Genetics, Breeding and Biotechnology, University of Life Sciences in Lublin, Poland

\begin{abstract}
Streszczenie. Niemal w każdym regionie uprawy owsa infekcja grzybem Puccinia coronata f. sp. avenae powoduje utratę plonu. Łagodne zimy i mokre lata sprzyjają infekcji, dlatego rdza koronowa pojawia się w Polsce co roku, powodując duże straty w ilości i jakości ziarna. Najlepszym sposobem kontrolowania rdzy koronowej jest wykorzystanie odporności warunkowanej genetycznie. Jest to sposób korzystny pod względem ekonomicznym, a także przyjazny dla środowiska. Stała ewolucja patogenu wymusza monitorowanie jego zjadliwości. Dlatego celem niniejszej pracy było scharakteryzowanie zjadliwości populacji $P$. coronata zebranych latem 2014 roku w centralnej i południowo-wschodniej Polsce w celu oceny efektywności znanych genów warunkujących odporność na rdzę koronową. Wirulencję populacji badano, wykorzystując siewki 27 linii referencyjnych z różnymi genami odporności oraz testy gospodarz-patogen prowadzone w warunkach kontrolowanej temperatury, wilgotności i oświetlenia. Populacje rdzy koronowej z różnych regionów uprawy owsa były zróżnicowane. Żadna z testowanych populacji $P$. coronata nie przełamywała odporności warunkowanej genami: Pc50, Pc52, Pc59, $P c 60, P c 71, P c 91$ oraz Pc94. Tylko jedna populacja grzyba była zjadliwa w stosunku do genu $P c 70$. Sporadycznie identyfikowano zjadliwość w odniesieniu do genów Pc48 i Pc68. Stosunkowo wysoką skutecznością charakteryzowały się również geny Pc39, Pc51, Pc56, Pc57, Pc58 i Pc104. Na podstawie uzyskanych wyników można stwierdzić, że populacje rdzy koronowej, występujące w centralnej i południowo-wschodniej Polsce, charakteryzuje stosunkowo niska wirulencja, w związku z czym wiele źródeł odporności na $P$. coronata jest nadal efektywnych, Geny Pc mogą być wprowadzane i łączone w formie piramid genowych w polskich odmianach owsa w celu zwiększenia spektrum odporności na rdzę koronową.
\end{abstract}

Key words: crown rust, host-patogen test, oat, Puccinia coronata, resistance genes.

Słowa kluczowe: rdza koronowa, test żywiciel-patogen, owies, Puccinia coronata, geny odporności.

\section{INTRODUCTION}

Oat (Avena sativa L.) is a valuable crop grown worldwide for food and feed industries. In Poland in 2015 the area planted to oats occupied 460.693 thousands of hectares placing the country in the top five oat producers globally (http://faostat3.fao.org, http://stat.gov.pl/).

Cultivated oat is affected by a number of fungal diseases, which can significantly reduce the amount and quality of yield. Crown rust, caused by Puccicnia coronata Cda. f. sp.

Corresponding author - Adres do korespondencji: Edyta Paczos-Grzęda, Institute of Plant Genetics, Breeding and Biotechnology, University of Life Sciences in Lublin, Akademicka 15, 20-950 Lublin, Poland, e-mail: edyta.paczos@up.lublin.pl 
avenae P. Syd. \& Syd., is the most widespread and harmful oat disease with almost every region of oat cultivation suffering losses caused by this pathogen (Chong 2003). P. coronata is a highly adaptable and ubiquitous obligatory parasite with a complex, macrocyclic life cycle. It produces five distinct spore forms and is heteroecious, needing both primary and alternate hosts to complete its life cycle (Agrios 2013; Chaves et al. 2008). Symptoms of crown rust include orange pustules of spores developing on all aerial green parts of the plant such as leaf sheaths, panicles and even floral structures, but especially leaves. Infected plants develop a reduced root system resulting in diminished drought tolerance. The disease also decreases the quality of the straw, which exacerbates lodging. It affects plant vegetation, hinders harvest and enhances susceptibility to other pathogens (Simons 1985; Gnanesh et al. 2014b).

The frequency of oat crown rust occurrence in Poland, especially in the south-east, has increased recently. One possible explanation could be the lack of resistant Polish oat cultivars (Paczos-Grzęda et al. 2014). Moreover, prevailing weather conditions such as mild winters, late spring and wet summers may support infection (Simons 1985). The virulence of $P$. coronata is not well characterised in Poland, prompting the current study of 27 reference lines to establish the effect of a range of $P c$ genes.

\section{MATERIAL AND METHODS}

Virulence of $P$. coronata populations in central and south-eastern Poland was evaluated on a set of 27 reference lines, each representing a single major gene resistance to crown rust. Samples of $P$. coronata f. sp. avenae were obtained from leaves with symptoms of crown rust during the summer of 2014. Populations were collected at random farm fields in Sufczyn, Opole Lubelskie, Puławy, Radzików, Solec nad Wisłą and Frampol as well as the field plots of Polish breeding companies (Polanowice, Strzelce) and the experimental farm of the University of Life Sciences in Lublin (Czesławice). Each population was gathered from one field by combining leaves with rust symptoms collected randomly in 10 places spaced approximately $10 \mathrm{~m}$ apart from each other. Samples from Polanowice, Strzelce and Czesławice were collected from two separate experimental fields (Fig. 1).

The samples were multiplied in a phytotron on the susceptible oat cultivar 'Kasztan' following the host-pathogen test methodology of Hsam et al. (1997). Ten day old $3 \mathrm{~cm}$ long fragments of 'Kasztan' leaves were placed on Petri dishes containing agar $(0.6 \%)$ and benzimidazole (3.4 mM). Dishes were inoculated in a settling tower by spreading uredinospores onto the plant material at a density of $500-700$ spores $\cdot \mathrm{cm}^{-2}$. After inoculation, plates were incubated for $20 \mathrm{~h}$ in the dark at $100 \%$ humidity and temperature of $18^{\circ} \mathrm{C}$, and thereafter for 10 days in a growth chamber at $18^{\circ} \mathrm{C}$ under a $14 \mathrm{~h}$ photoperiod with light intensity reaching $4 \mathrm{kLx}$ and $70 \%$ humidity.

The virulence of the fungal samples was tested on seedlings of 27 reference lines with diverse $P c$ genes by means of host-pathogen tests under controlled temperature, humidity and lighting conditions mentioned above. The differential near-isogenic lines $P c 51, P c 52, P c 70$, $P c 71$ were developed at lowa State University, USA and the lines Pc39, Pc40, Pc45, Pc48, Pc50, Pc54, Pc55, Pc56, Pc57, Pc62, Pc67, Pc68, Pc91, Pc94, Pc96, Pc97, Pc98, Pc101, $P c 103-1$, and $P c 104$ were developed at the Cereal Research Centre AAFC Winnipeg, Canada (Carson 2011; Chong et al. 2011; Menzies et al. 2015). Pc58, Pc59 and Pc60 were 
represented by 'TAM-O-301', 'TAM-O-312', 'Coker227', and 'Coker234', respectively (Simons et al. 1978). Seeds of the 27 reference oat lines were placed on plug trays filled with a universal substrate mixed with peat, and allowed to germinate. $3 \mathrm{~cm}$ leaf fragments of young seedlings were collected after 10 days and placed on to 12-well culture plates filled with agar (0.6\%) with the addition of benzimidazole (3.4 mM). Three leaves fragments, each from a different seedling of one reference oat line, were placed on each plate. Leaves of the susceptible cultivar 'Kasztan' were put into each well as an infection control. Plates containing leaves were inoculated with the selected $P$. coronata samples and incubated as above.

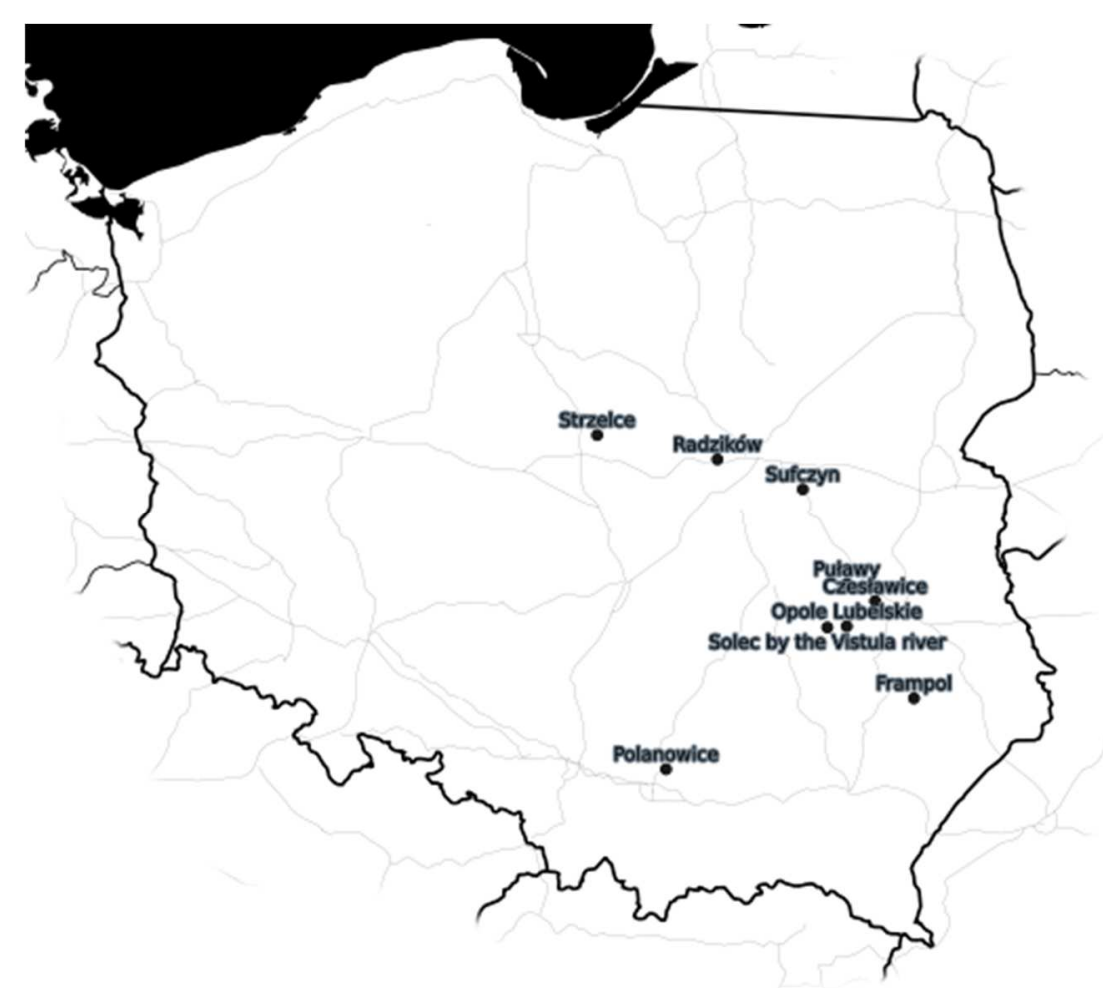

Fig. 1. The geographical locations where oat crown rust populations were collected Ryc. 1. Miejsca, w których zbierano populacje rdzy koronowej

Assessment of leaf infection was performed after 12 days using a qualitative scale of $\mathrm{S}$, $M S, M R, R$, and $H R$, where reaction phenotypes were:

$S$ - susceptible, large to moderately large pustules with little or no chlorosis;

MS - moderately susceptible, moderately large pustules surrounded by extensive chlorosis;

MR - moderately resistant, small pustule surrounded by chlorosis;

$\mathrm{R}$ - resistant, chlorotic or necrotic flecking;

$\mathrm{HR}$ - highly resistant, no visible reaction.

\section{RESULTS}

The crown rust populations from diverse oat growing regions were clearly distinguished. The most aggressive, inducing susceptible (S) or moderately susceptible (MS) response in 15 evaluated reference lines was the population 1 from Czesławice. Samples Sufczyn, Opole Lubelskie and Polanowice 1 overcame the resistance of $14 P c$ lines tested, while Strzelce 2, Puławy and Polanowice 2 were virulent toward 13,13 and $12 P c$ reference lines respectively. 
Table 1. Sensitivity of lines with resistance genes to $P$. coronata collected in central and south-eastern Poland in 2014

Tabela 1. Wrażliwość linii z genami odporności na populacje $P$. coronata, zgromadzone w centralnej i południowo-wschodniej Polsce w 2014 roku

\begin{tabular}{|c|c|c|c|c|c|c|c|c|c|c|c|c|}
\hline \multirow[b]{2}{*}{$\begin{array}{l}P c \text { line } \\
\text { Linia } P C\end{array}$} & \multicolumn{12}{|c|}{$\begin{array}{l}\text { P. coronata populations } \\
\text { Populacje } P \text {. coronata }\end{array}$} \\
\hline & $\begin{array}{c}\text { Czesławice } \\
1\end{array}$ & $\begin{array}{c}\text { Czesławice } \\
2\end{array}$ & Frampol & $\begin{array}{c}\text { Opole } \\
\text { Lubelskie }\end{array}$ & $\begin{array}{c}\text { Polanowice } \\
1\end{array}$ & $\begin{array}{l}\text { Polanowice } \\
2\end{array}$ & Puławy & Radzików & $\begin{array}{c}\text { Solec by the } \\
\text { Vistula river } \\
\text { Solec nad } \\
\text { Wisła }\end{array}$ & Strzelce 1 & Strzelce 2 & Sufczyn \\
\hline$P c 39$ & MS & MS & $\mathrm{R}$ & $\mathrm{R}$ & MS & $R$ & $\mathrm{R}$ & $S$ & $\mathrm{R}$ & HR & $\mathrm{R}$ & MS \\
\hline Pc 40 & $S$ & MS & $\mathrm{R}$ & $S$ & $\mathrm{~s}$ & $S$ & $S$ & HR & $S$ & $\mathrm{R}$ & $S$ & MS \\
\hline Pc 45 & $S$ & MS & $\mathrm{R}$ & $S$ & $S$ & $S$ & $S$ & $\mathrm{HR}$ & $\mathrm{R}$ & $\mathrm{R}$ & S & MS \\
\hline Pc 48 & $\mathrm{R}$ & $\mathrm{R}$ & $\mathrm{R}$ & $\mathrm{R}$ & $\mathrm{R}$ & MS & MS & MR & $\mathrm{R}$ & $\mathrm{R}$ & $\mathrm{R}$ & $\mathrm{HR}$ \\
\hline Pc 50 & $\mathrm{HR}$ & HR & HR & $\mathrm{R}$ & $\mathrm{R}$ & $\mathrm{R}$ & $\mathrm{R}$ & $\mathrm{HR}$ & HR & $\mathrm{HR}$ & $\mathrm{HR}$ & MR \\
\hline$P_{C} 51$ & $S$ & MS & $\mathrm{HR}$ & $S$ & $\mathrm{R}$ & $\mathrm{R}$ & $\mathrm{R}$ & HR & $\mathrm{HR}$ & $\mathrm{HR}$ & $S$ & $\mathrm{R}$ \\
\hline Pc 52 & $\mathrm{R}$ & $\mathrm{R}$ & $\mathrm{R}$ & $\mathrm{R}$ & $\mathrm{R}$ & $\mathrm{R}$ & $\mathrm{R}$ & HR & $\mathrm{R}$ & $\mathrm{HR}$ & $\mathrm{R}$ & $\mathrm{HR}$ \\
\hline Pc 54 & $S$ & $\mathrm{R}$ & $\mathrm{R}$ & $S$ & $S$ & $S$ & $S$ & MR & $\mathrm{R}$ & MR & $S$ & $S$ \\
\hline Pc 55 & MS & $\mathrm{R}$ & $\mathrm{R}$ & MS & MS & $\mathrm{R}$ & $\mathrm{R}$ & MS & $\mathrm{R}$ & MR & MS & MS \\
\hline Pc 56 & $\mathrm{R}$ & $\mathrm{R}$ & $S$ & $\mathrm{R}$ & MS & $R$ & $\mathrm{R}$ & MS & $S$ & $\mathrm{R}$ & $\mathrm{R}$ & $\mathrm{R}$ \\
\hline Pc 57 & $S$ & $\mathrm{R}$ & $\mathrm{R}$ & MS & MS & $\mathrm{R}$ & MR & MR & $\mathrm{R}$ & $S$ & MS & $\mathrm{R}$ \\
\hline Pc 58 & $\mathrm{R}$ & $\mathrm{R}$ & $\mathrm{R}$ & MR & $\mathrm{R}$ & $\mathrm{R}$ & MS & $\mathrm{HR}$ & MS & $\mathrm{HR}$ & $R$ & MS \\
\hline Pc 59 & HR & $\mathrm{R}$ & $\mathrm{R}$ & $\mathrm{R}$ & MR & $\mathrm{R}$ & $\mathrm{R}$ & MR & $\mathrm{R}$ & $\mathrm{HR}$ & $\mathrm{R}$ & $\mathrm{R}$ \\
\hline Pc 60 & $\mathrm{R}$ & $\mathrm{R}$ & $\mathrm{R}$ & $\mathrm{R}$ & MR & $\mathrm{R}$ & $\mathrm{R}$ & MR & $\mathrm{R}$ & $\mathrm{R}$ & $\mathrm{R}$ & MR \\
\hline Pc 62 & MS & MR & $S$ & MS & MS & $S$ & MS & $\mathrm{R}$ & $\mathrm{R}$ & $\mathrm{R}$ & MS & MS \\
\hline Pc 67 & $\mathrm{R}$ & $\mathrm{HR}$ & $\mathrm{s}$ & MS & $\mathrm{s}$ & MS & MS & $\mathrm{HR}$ & MS & MS & $\mathrm{HR}$ & MS \\
\hline Pc 68 & MS & MS & HR & $\mathrm{HR}$ & HR & $\mathrm{HR}$ & $\mathrm{HR}$ & HR & $\mathrm{HR}$ & $\mathrm{HR}$ & MR & $\mathrm{HR}$ \\
\hline Pc 70 & $\mathrm{R}$ & $\mathrm{R}$ & $\mathrm{R}$ & $\mathrm{R}$ & $\mathrm{R}$ & $\mathrm{R}$ & $\mathrm{R}$ & MR & $\mathrm{R}$ & $\mathrm{R}$ & $\mathrm{R}$ & MS \\
\hline Pc 71 & $\mathrm{HR}$ & $\mathrm{HR}$ & $\mathrm{HR}$ & $\mathrm{R}$ & MR & $\mathrm{R}$ & $\mathrm{R}$ & $\mathrm{R}$ & HR & $\mathrm{HR}$ & $\mathrm{R}$ & MR \\
\hline Pc 91 & HR & $\mathrm{R}$ & $\mathrm{HR}$ & $\mathrm{HR}$ & HR & HR & $\mathrm{HR}$ & HR & HR & $\mathrm{HR}$ & $\mathrm{HR}$ & $\mathrm{HR}$ \\
\hline Pc 94 & MR & HR & $\mathrm{R}$ & HR & MR & $\mathrm{R}$ & $\mathrm{R}$ & HR & $\mathrm{HR}$ & $\mathrm{HR}$ & $\mathrm{R}$ & $\mathrm{HR}$ \\
\hline Pc 96 & MS & $\mathrm{R}$ & $\mathrm{R}$ & MS & MS & $S$ & MS & $\mathrm{R}$ & HR & $\mathrm{R}$ & MS & MS \\
\hline Pc 97 & MS & $\mathrm{R}$ & MR & MS & MS & $S$ & $S$ & MS & HR & $\mathrm{R}$ & MS & MS \\
\hline Pc 98 & MS & $\mathrm{R}$ & $\mathrm{HR}$ & MS & MS & $\mathrm{s}$ & S & $\mathrm{R}$ & $R$ & $\mathrm{R}$ & MS & MS \\
\hline$P c 101$ & MS & $S$ & $\mathrm{HR}$ & MS & MS & MS & $S$ & $\mathrm{HR}$ & HR & $\mathrm{HR}$ & $S$ & MS \\
\hline Pc 103-1 & $\mathrm{s}$ & $\mathrm{HR}$ & MR & MS & $S$ & $\mathrm{~s}$ & $\mathrm{~s}$ & MS & MR & $\mathrm{R}$ & $S$ & MS \\
\hline Pc 104 & $\mathrm{~s}$ & $\mathrm{HR}$ & $\mathrm{HR}$ & 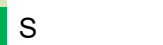 & $\mathrm{R}$ & S & MS & $\mathrm{HR}$ & $\mathrm{R}$ & $\mathrm{HR}$ & S & $\mathrm{HR}$ \\
\hline
\end{tabular}


A much lower level of virulence was demonstrated by samples collected in Czesławice (Czesławice 2 - 6 broken resistance genes), Radzików (5 broken resistance genes), Solec nad Wisłą (4 broken resistance genes) and Frampol (3 broken resistance genes). Strzelce 1 was found to be the population with the lowest virulence showing reaction of crown rust susceptibility to 2 of the 27 tested reference lines (Table 1, Fig. 2).

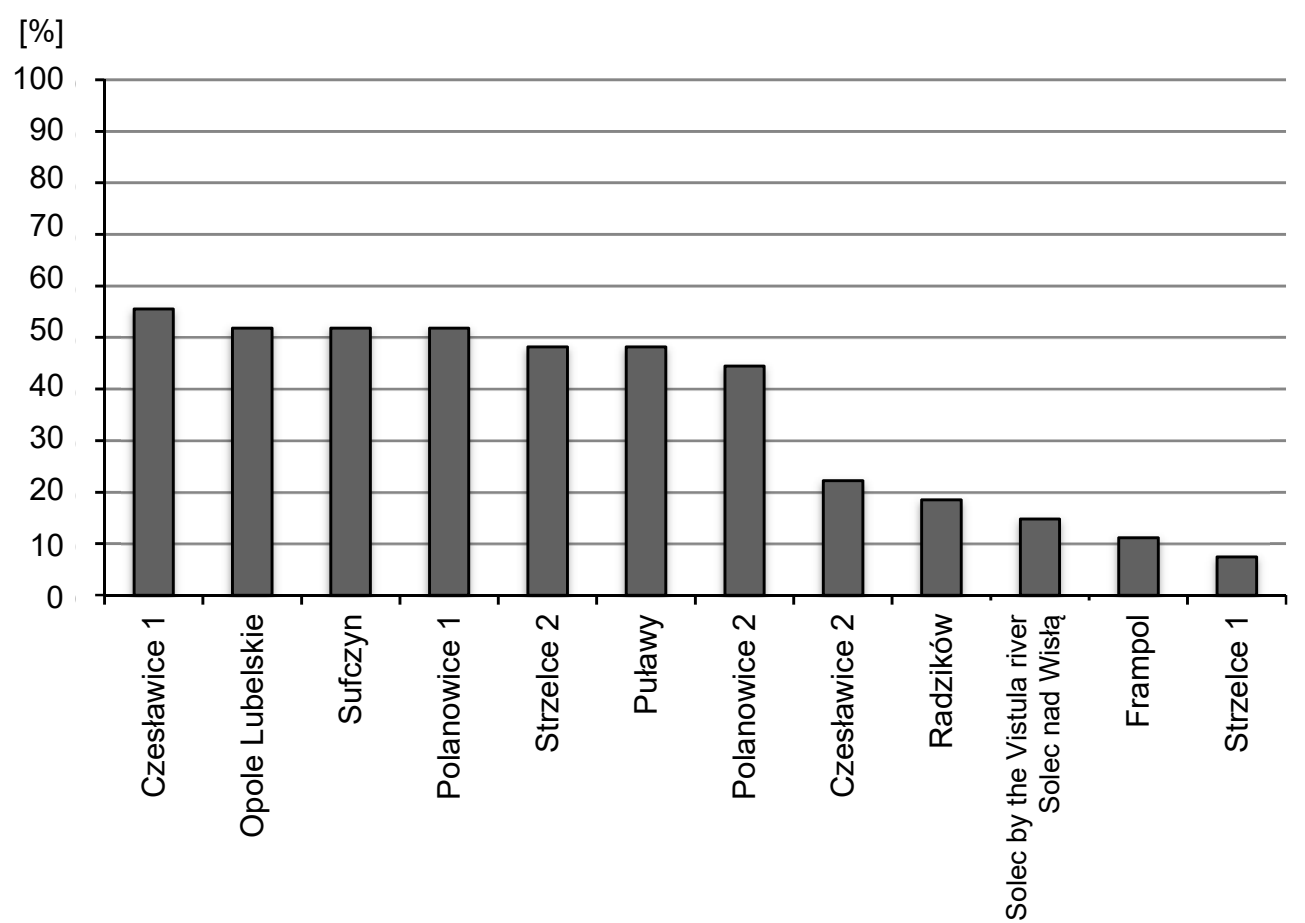

Fig. 2. Relative virulence of the collected samples of $P$. coronata to the tested Avena sativa lines carrying different $P c$ resistance genes

Ryc. 2 Względna wirulencja zgromadzonych izolatów w odniesieniu do linii referencyjnych z różnymi genami odporności $P C$

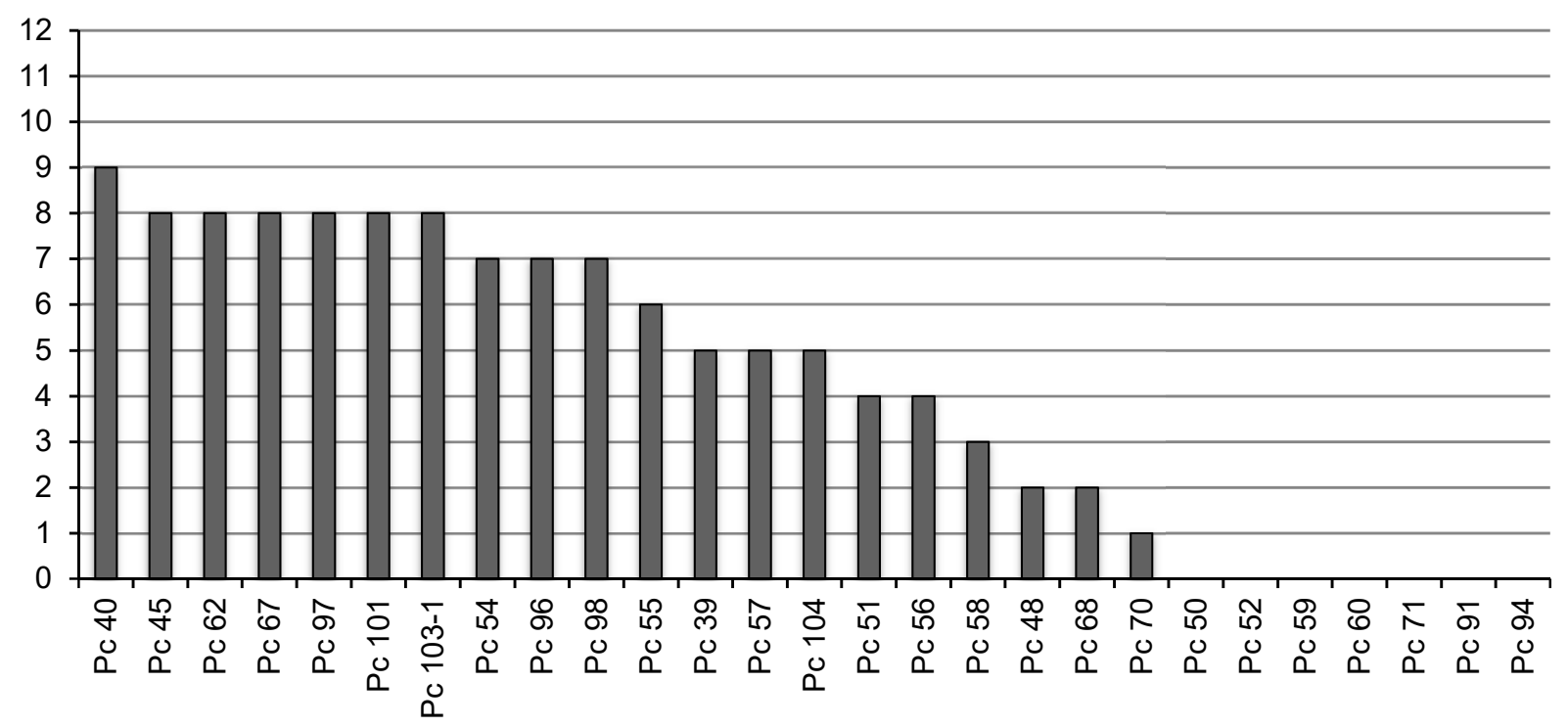

Fig. 3. Effectiveness of tested resistance genes based on a number of $P$. coronata populations virulent towards these genes

Ryc. 3. Efektywność testowanych genów odporności na podstawie liczby populacji $P$. coronata wirulentnych wobec tych genów 
The most effective genes at the seedling stage were Pc50, Pc52, Pc59, Pc60, Pc71, Pc91, $P c 94$, which provided resistance to all tested $P$. coronata samples. Only one sample was virulent for lines containing $P c 70$ genes. Occasional virulence was observed toward $P c 48$ and $P c 68$. Relatively effective resistance was also seen for $P c 58$ (overcome by $3 P$. coronata samples), Pc51 and Pc56 (overcome by 4 P. coronata samples) and Pc39, Pc57 and Pc104 (overcome by $5 P$. coronata samples). Other $P c$ genes were defeated by more than five of the tested populations. The lowest efficiency was shown by Pc40 which conferred resistance to only 3 populations of oat crown rust (Table 1, Fig. 3).

\section{DISCUSSION}

The present study is a part of the continuing effort to monitor the occurrence and harmfulness of oat crown rust populations in central and south-eastern Poland. The main objective was to evaluate the effectiveness of some known resistance genes in overcoming the virulence of the $P$. coronata populations in this region, in order to draw up a strategy for local oat breeding programs.

Infecting reference lines with different $P c$ genes by using multiplied populations allowed representative assessment of virulence occurring in a given geographical region. However samples taken at the same locations but from distinct field plots could differ in virulence, as seen for Strzelce, Polanowice and Czesławice. These locations hosted field trials of a number of oat genotypes with different resistance genes, leading to an expectation of high selection pressure and diversity within the occurring populations.

Resistance to crown rust by both new and historic Polish oat cultivars is at a very low level (Paczos-Grzęda et al. 2014), therefore virulence of crown rust populations stays relatively stable and many sources of resistance are still effective against crown rust races occurring in Poland. Out of all 27 tested lines, genes Pc50, Pc52, Pc59, Pc60, Pc71, Pc91, Pc94 were found to be the most effective in providing resistance to every $P$. coronata sample used in the host-pathogen tests. However the most efficient Pc genes Pc39, Pc51 and Pc68, were seen to be losing effectiveness. According to Róg et al (2015) these genes remained resistant until 2011, whereas infection of Pc40, Pc57 and Pc62 has significantly increased in comparison to the results obtained by these authors. Interestingly, genes Pc70 and Pc94 which have been broken according to authors cited above, in 2014 have demonstrated high level of resistance.

Information provided by monitoring oat rust populations is especially important for breeding programs to decide on strategies for breeding for resistance, in choosing existing genotypes for cultivation and combinations of genes for future selections. Host genetic resistance is the optimal approach to crown rust control for both economic and environmental reasons (Gnanesh et al. 2014b). Complete resistance to specific races of rust is provided by major genes via a gene-for-gene interaction (Flor 1955). However, when deployed singly these genes can be short lived, which is confirmed by studies carried out in USA, Canada and Australia where $P C$ genes are constantly incorporated into oat breeding programs (Cabral et al. 2014). Virulence against cultivars with only one effective resistance gene may occur quickly as in the case of 'Triple Crown' possessing Pc48 (Chong and Zegeye 2004). To increase durability and broaden the spectrum of resistance currently efficient $P c$ genes should be 
combined. The duration of pooled genes efficiency was proved to be much longer than those determined by single genes. Pc38 and Pc39 combinations were successfully deployed in many cultivars, with varieties such as 'Dumont', 'Robert' and 'Riel' providing resistance for about 15 years (Gnanesh et al. 2014a). Effective 'pyramids' of this combination have been created with additional crown rust resistance genes. $P c 38+P c 39$ with $P c 50$ in 'Cleanleaf' were unbroken for 3 years (Park 2013) and with Pc68 in 'AC Assiniboia' as well as 'AC Medallion' and many other cultivars resulted in 10 years resistance to crown rust in oats (Cabral et al. 2014). Pc68 was also successfully crossed with Pc94 in 'Leggett' (Mitchell Fetch et al. 2007) and remains effective in contrast to Pc68 used as a single crown rust resistance gene in 'Moola' and 'Graza 68' which was broken after 1-2 years (Park 2013). Cultivars with Pc91 such as 'HiFi' (McMullen et al. 2005) and 'Drover' (Park and Kavanagh 2009) also stay highly resistant, however $P$. coronata pathotypes with virulence against this gene have already been detected. The cultivar "Aladdin" hypothetically carrying Pc91 + Pc50 remains resistant to this new pathotype, possibly being protected by Pc50 (Park 2013).

Currently there are 30 Polish oat cultivars in Research Centre for Cultivar Testing (COBORU) registered (http://www.coboru.pl), however there is no accurate information on their resistance to $P$. coronata. Such data about the presence of crown rust resistance genes in Polish A. sativa cultivars are not available, but would be very useful for oat growers.

Results obtained in this study, as well as our previous reports (Róg et al. 2015), indicate that all resistance gene combinations mentioned above used in the USA, Canadian or Australian breeding programs, as well as other effective genes combinations should confer crown rust resistance in Polish conditions.

\section{CONCLUSIONS}

Crown rust populations from central and south-eastern Poland oat growing regions were distinguished, but proved relatively stable compared to previously published data. The most effective genotypes in seedling stage screens, resistant to all tested $P$. coronata samples, were genes Pc50, Pc52, Pc59, Pc60, Pc71, Pc91 and Pc94. Comparatively effective were also Pc70, Pc48, Pc68, Pc51, Pc56, Pc58 as well as Pc39, Pc57 and Pc104. These genes can be combined and introduced into the Polish oat cultivars.

Results show that many sources of resistance against crown rust races occurring in Poland are still effective, however we can already observe overcoming of the most efficient $P c$ genes. Combining $P C$ genes in one cultivar should significantly increase the durability and broaden the spectrum of oat resistance. Simultaneously the high pressure on the pathogen populations and necessity of unremitting efforts to maintain stable resistance should be considered .

\section{REFERENCES}

Agrios G.N. 2013. Plant pathology. London, UK, Elsevier.

Cabral A.L., Gnanesh B.N., Fetch J.M., Mccartney C., Fetch T., Park R.F., Menzies J.G., Mccallum B., Nanaiah G.K., Goyal A. 2014. Oat fungal diseases and the application of molecular marker technology for their control, in: Future challenges in crop protection against fungal pathogens. Eds. A. Goyal A., C. Manoharachary. New York, Springer Science+Business Media, 343-358. 
Carson M.L. 2011. Virulence in oat crown rust (Puccinia coronata f. sp. avenae) in the United States from 2006 through 2009. Plant Dis. 95(12), 1528-1534.

Centralny Ośrodek Badania Odmian Roślin Uprawnych, http://www.coboru.pl, access: 22 April 2017. [in Polish]

Chaves M.S., Martinelli J.A., Wesp C.L., Graichen F.A.S. de. 2008. The cereal rusts : an overview. Pest Technol. (2), 38-55.

Chong J. 2003. Disease of oat, in: Diseases of field crops in Canada. Eds. K. Bailey, B. Gossen, R. Gugel, R. Morrall. Saskatoon, Canada, CPS Press, 74-88.

Chong J., Gruenke J., Dueck R., Mayert W., Mitchell Fetch J.W., McCartney C.A. 2011. Virulence of Puccinia coronata f. sp. avenae in the eastern prairie region of Canada during 2007-2009. Can. J. Plant Pathol. 33(1), 77-87.

Chong J., Zegeye T. 2004. Physiologic specialization of Puccinia coronata f. sp. avenae, the cause of oat crown rust, in Canada from 1999 to 2001. Can. J. Plant Pathol. 26(1), 97-108.

Flor H.H. 1955. Host - parasite interaction in flax rust - its genetics and other implications. Phytopathology 1(45), 680-685.

Food and Agriculture Organization of the United Nations (FAO) Statistics division, http://faostat3.fao.org, access: 22 April 2017.

Główny Urząd Statystyczny, http://stat.gov.pl/, access: 10 April 2017. [in Polish]

Gnanesh B.N., Fetch J.M., Zegeye,T., McCartney C.A., Fetch T. 2014a. Oat, in: Alien gene transfer in crop plants. Eds. A. Pratap, J. Kumar. New York, Springer, 51-73.

Gnanesh B.N., McCartney C.A., Eckstein P.E., Mitchell Fetch J.W., Menzies J.G., Beattie A.D. 2014b. Genetic analysis and molecular mapping of a seedling crown rust resistance gene in oat. Theor. Appl. Genet. 128, 247-258.

Hsam S.L.K., Peters N., Paderina E.V., Felsenstein F., Oppitz K., Zeller F.J. 1997. Genetic studies of powdery mildew resistance in common oat (Avena sativa L.). I. Cultivars and breeding lines grown in Western Europe and North America. Euphytica 96, 421-427.

McMullen M.S., Doehlert D.C., Miller J.D. 2005. Registration of 'HiFi' oat. Crop Sci. 45, 1664-1664.

Menzies J.G., Xue A., Dueck R., Greunke J. 2015. Virulence of Puccinia coronata f. sp. avenae in Canada; 2010 to 2014, in: 14th International Cereal Rust and Powdery Mildew Conference, Copenhagen, Denmark, 5-8 July 2015, Copenhagen, [b.w.], 95.

Mitchell Fetch J.W., Duguid S.D., Brown P.D., Chong J., Fetch T.G., Haber S.M., Menzies J.G., Ames N., Noll J., Aung T., Stadnyk K.D. 2007. Leggett oat. Can. J. Plant Sci. 87(3), 509-512.

Paczos-Grzęda E.M., Okoń S.M., Koroluk A., Kowalczyk K. 2014. Ocena odporności na rdzę koronową nowych i historycznych polskich odmian owsa zwyczajnego [Assessing crown rust resistance of modern and old Polish oat cultivars]. Folia Pomer. Univ. Technol. Stetin., Agric., Aliment. Pisc., Zootech. 310(30), 85-92. [in Polish]

Park R. 2013. New oat crown rust pathotype with virulence for Pc91. Cer. Rust Rep. 11(1), 8-10.

Park R., Kavanagh P. 2009. Cereal rust survey - annual report 2008-2009. Cobbitty, [b.w.].

Róg S., Paczos-Grzęda E., Koroluk A., Okoń S.M., Ostrowska A., Erdzik P., Chrząstek M., Gruszecka D. 2015. The efficiency of crown rust resistance genes in common oat against Puccinia coronata pathotypes in central and south-eastern Poland in 2010-2011. Ann. UMCS, Sect. Agric. 70(2), 97-105.

Simons M.D. 1985. Crown rust, in: The cereal rust. Vol. 2. Diseases. Distribution. Epidemiology, and control. Eds. A.P. Roelfs, W.R. Bushnel. Orlando, Academic Press, 131-172.

Simons M.D., Martens J.W., McKenzie R.I.H., Nishiyama I., Sadanaga K., Sebesta J., Thomas H. 1978. Oats: a standardized system of nomenclature for genes and chromosomes and catalog of genes governing characters. Washington, D.C., Science and Education Administration, and lowa Agricultural and Home Economics Experiment Station. 


\begin{abstract}
Losses caused by Puccinia coronata f. sp. avenae are an almost universal problem for oat growers. Mild winters and wet summers are conducive to fungal growth, leading to recurrent annual infection in Poland and consequent high losses in yield and grain quality. Host genetic resistance is the preferred approach to control crown rust on both economic and environmental grounds. However, rapid evolution of the pathogen leads to risk of breakdown of resistance, and hence to a constant need to monitor crop susceptibility. The objective of this work was to characterize the virulence of $P$. coronata populations collected during the summer of 2014 in central and south-eastern Poland to evaluate the effectiveness of some known crown rust resistance genes in oats. Virulence was studied using seedlings of 27 reference lines containing different $P c$ genes by means of host-pathogen tests under conditions of controlled temperature, humidity and lighting. Crown rust populations from diverse oat-growing regions were clearly distinguished. All tested P. coronata samples were avirulent toward Pc50, Pc52, Pc59, Pc60, $P c 71, P c 91$, Pc94 genes. Only one sample was virulent, if resistance was covered by Pc70. Occasional virulence was observed toward $P c 48$ and $P c 68$. Tested $P$. coronata samples defeated resistance of $P c 51, P c 56, P c 58$ as well as $P c 39, P c 57$ and $P c 104$ differential lines relatively rare. Results showed that crown rust populations occurring in central and south-eastern Poland characterized relatively low virulence, and because of the fact many sources of resistance against $P$. coronata are still effective. $P c$ genes can be introduced and combined in form of gene pyramids into Polish oat cultivars in order to increase the crown rust resistance spectrum.
\end{abstract}

The study was granted by Ministry of Agriculture and Rural Development of the Republic of Poland, Grant 2014-2020: "Crown rust resistance gene pyramiding in oat genome and identification of DNA markers for these genes". 
